\title{
Article \\ The influence of cooling rate during welding on joint properties made of austenitic steel 1.4301
}

\author{
Agnieszka Rzeźnikiewicz ${ }^{1, *}$, Mateusz Makielak ${ }^{1}$, Piotr Dyner ${ }^{2}$ \\ ${ }^{1}$ Silesian University of Technology, Poland \\ Mateusz Makielak; mateusz.amakielak@gmail.com; \\ 2 CHEMET S.A. \\ Piotr Dyner; pdyner@chemet.com.pl; \\ * Correspondence: Agnieszka Rzeźnikiewicz, Ph.D.; agnieszka.rzeznikiewicz@polsl.pl
}

Received: 16.06.2019; Accepted: 11.10.2019

\begin{abstract}
The aim of the research was to investigated the influence of cooling rate during welding on joint properties made of austenitic steel 1.4301. Three test panels were made: cooled in air, cooled by dipping the plate in water and cooled by spraying water from the side of the weld ridge. Non-destructive examinations (visual, penetrative and radiographic) and destructive tests (stretching, bending and impact tests) were made on the test panels. In addition, the ferrite content measurement was carried out. It has been shown that the cooling affects the ferrite content and the impact strength of the joint.
\end{abstract}

Keywords: austenitic steel; cooling during welding; technology qualification

\section{Introduction}

The current stage of development of material engineering is characterized by the search for quantitative relationships between chemical composition, parameters, technological, structure and material properties. These compounds are the basis for the selection of materials and technologies for their production. They also enable the selection of operational properties of welded joints and forecasting the durability and reliability of welded structures $[1 \div 8]$.

One of the most commonly used corrosion resistant steels are chromium-nickel austenitic steels. Thanks to the appropriate nickel content, it is possible to obtain an austenitic structure. Most often they contain $18 \%$ chromium, which makes them characterized by very good corrosion resistance, and thus become universal, as they can be used in various environments. The microstructure of austenitic steel welds depends on the crystallization method and solid state transformations. The chromium and nickel equivalent plays an important role here, because for steels with a higher ratio of these equivalents, $\delta$ ferrite is released during crystallization, while for steels with a lower ratio, austenite is released. The literature defines four types of solidification in joints defined as follows: A, AF, FA, F. Their dependence is shown in figure $1[2,7,9 \div 14]$.

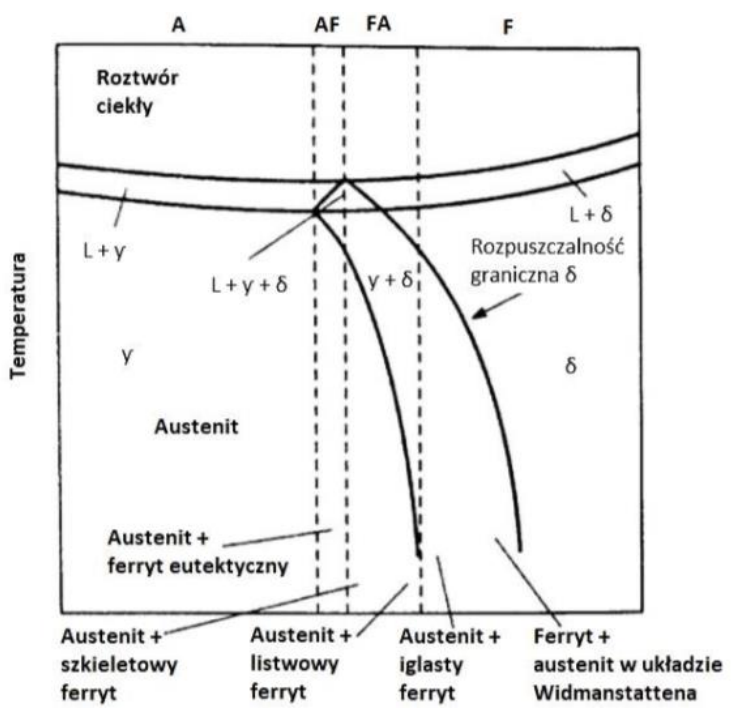

Fig. 1. Dependence of the ratio of chromium to nickel equivalents on the type of crystallization of welds in the joints of welded austenitic steels [9] 
Type A is one in which the weld crystallizes with the precipitation of primary austenite and does not experience changes during cooling. If $\delta$ ferrite forms in the weld as a result of the transformation in the final phase of crystallization, it is type AF. Due to the presence of ferrite-forming elements such as chromium and molybdenum, ferrite remains stable and does not undergo transformation during rapid cooling. For an even greater ratio of chromium to nickel, ferrite crystallizes as the primary phase, which during cooling as a result of massive transformation, partially undergoes transformation into austenite located at the borders of dendrites and ferrite grains (FA). With an even greater increase in this ratio, the proportion of austenite decreases until crystallization begins to be purely ferritic $(F)[2,7,9 \div 14]$.

\section{Purpose and course of the research}

The purpose of the work was to determine the effect of heat dissipation rate during the welding process on the microstructure and mechanical properties of the welded joint made of austenitic steel 1.4301. Welding tests of test panels were performed with air cooling (marked as 1), immersion of the board in water (marked as 2) and using water spray from the ridge side (marked as 3). The welding process was carried out in workshop conditions. The proposed welding technology included making a root run with the TIG method using a backward-stepwise run. The root run of each of the plates was made with air-cooling. Filling runs were made by welding with covered electrode. The first test plate was welded with a coated electrode, maintaining the interpass temperature at a level not higher than $150{ }^{\circ} \mathrm{C}$. Another plate was welded while dipped in water. The last test plate was welded with a simultaneous spray of water from the ridge side. With this test, each subsequent run could be placed immediately after welding the previous run because of the high speed of heat removal.

The test material, were test plates made of 1.4301 steel (X5CrNi18-10, AISI 304) with dimensions of $150 \times 600 \times 10 \mathrm{~mm}$, beveled at $\mathrm{V}$ at an angle of $60^{\circ}$. The distance between the plates was $3 \mathrm{~mm}$. The chemical composition of steel in accordance with the manufacturer's certificate is given in table I.

Table I. Chemical composition of 1.4301 steel according to the manufacturer's approval

\begin{tabular}{|c|c|c|c|c|c|c|c|}
\hline \multicolumn{8}{|c|}{ Element content [\% by mass] } \\
\hline $\mathrm{C}$ & Si & Mn & $\mathrm{Ni}$ & $\mathrm{Cr}$ & $\mathbf{N}$ & $\mathrm{S}$ & $\mathbf{P}$ \\
\hline 0.028 & 0.51 & 1.59 & 8.04 & 18 & 0.068 & 0.007 & 0.029 \\
\hline
\end{tabular}

The additional material used for welding the root run by the TIG method was AVESTA 308L-Si/MVR$\mathrm{Si}$ wire with a diameter of $2 \mathrm{~mm}$. Filling runs were made with an AVESTA 308L/MVR coated electrode with a diameter of $4.0 \mathrm{~mm}$.

The qualification of welding plates 1,2 and 3 was carried out in accordance with the PN-EN ISO 15614-1 „Specification and qualification of welding procedures for metallic materials - Welding procedure test Part 1: Arc and gas welding of steels and arc welding of nickel and nickel alloys". In addition, ferrite content was tested.

\section{Non-destructive testing}

Visual, penetration and radiographic tests were performed for the test plates made.

Visual tests were carried out in accordance with the requirements of PN-EN ISO 17637:2017-02 “Nondestructive testing of welds - Visual testing of fusion-welded joints". 100\% of the weld and heat affected zone (HAZ) were tested. There were no welding imperfections, which allowed the submission of the sample for further testing.

Penetration tests were carried out in accordance with the requirements of PN-EN ISO 3452-2:2014-02 "Non-destructive testing - Penetrant testing - Part 2: Testing of penetrant materials". $100 \%$ of the welded joints were tested. There were no indications that there were any welding imperfections. An example of a joint after penetration tests is shown in figure 2 .

Radiographic tests were performed in accordance with PN-EN ISO 17636-2:2013-06 "Non-destructive testing of welds - Radiographic testing - Part 2: X - and gamma-ray techniques with digital detectors". Based on the radiographic analysis, no welding imperfections were found. An example of a radiogram is shown in figure 3.

In addition to the tests contained in PN-EN ISO 15614-1: 2017-08 "Specification and qualification of welding procedures for metallic materials - Welding procedure test - Part 1: Arc and gas welding of steels and arc welding of nickel and nickel alloys", ferrite $\delta$ level test was performed, which made it possible to assess the impact of heat removal speed on its content in the weld. The scope included native material 
area and weld. The tests were carried out with a Ferritscope FMP30 ferritometer. The measurement results are presented in table II. The volume fraction of ferrite $\delta$ in the austenitic weld material depending on the operating conditions is strictly defined. In the case of austenitic steels, it is important to maintain the ferrite content in the welds in the ranges specified by the standards, from 2 to $8 \%$, because only the optimal ferrite content guarantees good corrosion and fatigue protection of the welds. If the ferrite content in the welded joint is too low, then the welded material has a tendency to hot cracking, if the ferrite content is too high, then the strength, ductility and corrosion resistance deteriorate.

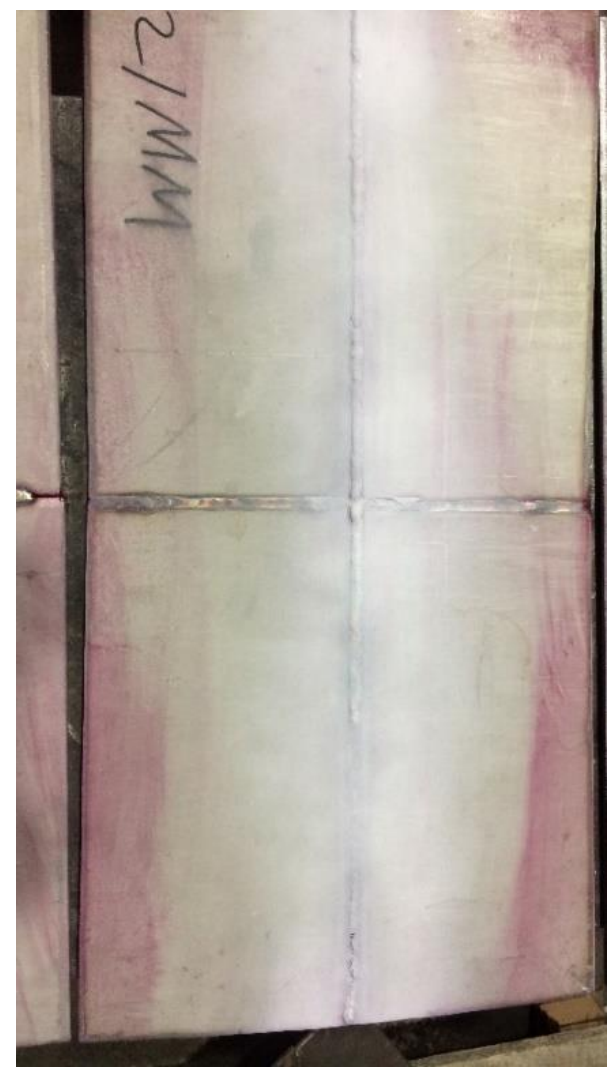

Fig. 2. View of plate no. 2 (cooled by immersion in water) after penetration tests

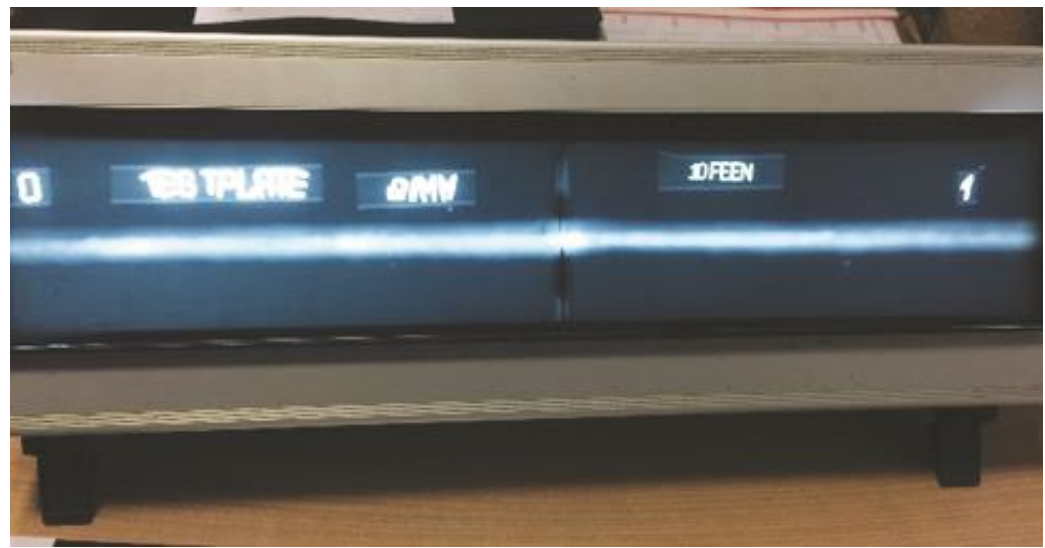

Fig. 3. Radiograph view for joint no. 2 (plate cooled by immersion in water)

Table II. Results of ferrite $\delta$ content measurement

\begin{tabular}{cccc}
\hline $\begin{array}{c}\text { Sample's } \\
\text { designation }\end{array}$ & $\begin{array}{c}\text { Ferrite content } \delta[\% \mathrm{Fr}] \\
\text { Ferrite number [FN] }\end{array}$ & Weld & \multicolumn{2}{c}{ Measurement area } \\
Native material \\
\hline \multirow{2}{*}{1} & $\% \mathrm{Fr}$ & 7.5 & 1.2 \\
& $\mathrm{FN}$ & 6.9 & 1.3 \\
2 & $\% \mathrm{Rr}$ & 6.9 & 1.4 \\
& $\mathrm{FN}$ & 6.0 & 1.3 \\
3 & $\% \mathrm{Fr}$ & 6.5 & 1.0 \\
& $\mathrm{FN}$ & 5.4 & 1.0 \\
\hline
\end{tabular}




\section{Destructive testing}

As part of the destructive tests, a static tensile, bend, and impact test was performed. The stretching of the welded joints was carried out on the MTS C64.605 testing machine. The test results are presented in table III. The bending test of welded joints of test plates from the face and from the side of the ridge was carried out on the MTS C64.605 testing machine. Two bending tests were carried out from the face and two from the ridge. The results are shown in table IV.

Table III. Results of the static tensile test of samples taken from welded joints made of 1.4301 steel

\begin{tabular}{cccccc}
\hline $\begin{array}{c}\text { Sample's } \\
\text { designation }\end{array}$ & $\begin{array}{c}\text { Cross-section } \\
\text { S }_{\mathbf{~}\left[\mathbf{m m}^{2}\right]}\end{array}$ & $\begin{array}{c}\text { Breaking } \\
\text { force } \\
\mathbf{F m}_{\mathbf{m}}[\mathbf{k N}]\end{array}$ & $\begin{array}{c}\text { Tensile } \\
\text { strength } \\
\mathbf{R}_{\mathbf{m}}{ }^{*}[\mathbf{M P a}]\end{array}$ & $\begin{array}{c}\text { Place of the } \\
\text { breakthrough }\end{array}$ & Imperfections \\
\hline 1.1 & 235.8 & 144.9 & 614.4 & Weld & - \\
1.2 & 226.6 & 139.57 & 615.9 & Weld & - \\
2.1 & 224.9 & 138.88 & 617.4 & Weld & - \\
2.2 & 225.1 & 137.96 & 612.6 & Weld & - \\
3.1 & 222.5 & 137.08 & 616.0 & Weld & - \\
\hline 3.2 & 227.9 & 140.56 & 616.4 & Weld & - \\
\hline
\end{tabular}

${ }^{*} \mathrm{Min} 540 \mathrm{MPa}$

Table IV. Results of the static bending test of samples taken from welded joints made of 1.4301 steel

\begin{tabular}{ccccc}
\hline Sample's designation & Bending side & Bending angle, $^{\circ}$ & Comments $^{\circ}$ \\
\hline 1.1 & Ridge & 180 & Flawless \\
1.1 & Face & 180 & Flawless \\
1.2 & Ridge & 180 & Flawless \\
& 1.2 & Face & 180 & Flawless \\
\hline & 2.1 & Ridge & 180 & Flawless \\
& 2.1 & Face & 180 & Flawless \\
2.2 & Ridge & 180 & Flawless \\
& 2.2 & Face & 180 & Flawless \\
\hline 3.1 & Ridge & 180 & Flawless \\
& 3.1 & Face & 180 & Flawless \\
& 3.2 & Ridge & 180 & Flawless \\
& 3.2 & Face & 180 & Flawless \\
\hline
\end{tabular}

Impact tests were performed using a Charpy PSW30 L-1 hammer. The temperature of the samples during the test was $-60^{\circ} \mathrm{C}$. The results of the impact test are presented in table V. In order to reveal the structure of the welded joint, macro- and microscopic metallographic tests were performed using Adler's reagent (Fig. 4 and 5). Observation and recording of microstructure images was carried out using a Nikon ECLIPSE MA100 light microscope (Fig. 5).

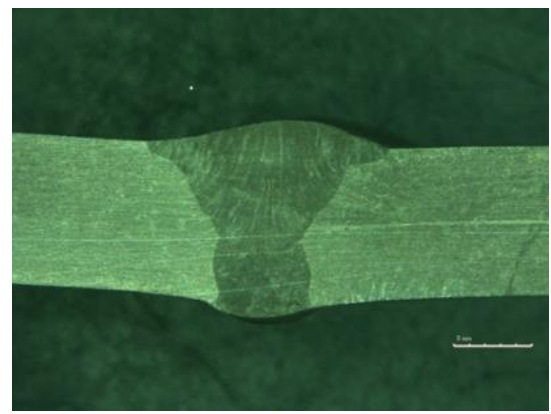

(a)

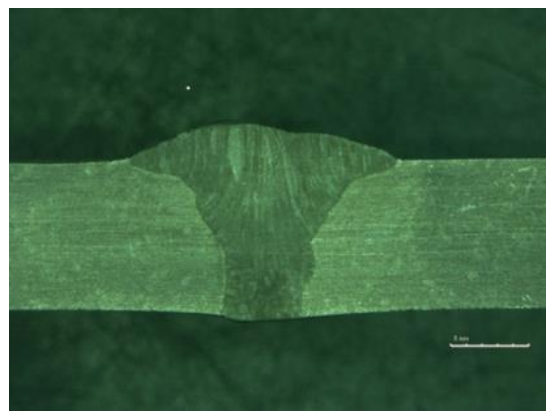

(b)

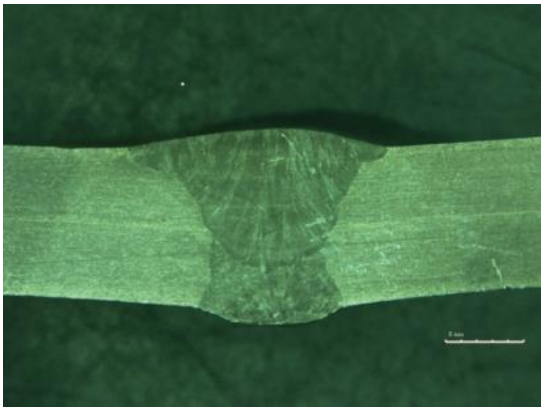

(c)

Fig. 4. Macrostructure of test plate joints made of 1.4301 steel: a) cooling in the air, b) cooling in water, c) cooling with water spray from the root side 
Table V. Results of the impact test of welded joints of test plates made of 1.4301 steel

\begin{tabular}{|c|c|c|c|c|}
\hline Sample's designation & Notch position & Impact energy [J] & Average score $[\mathrm{J}]$ & Defects detected \\
\hline 1.1 & \multirow{3}{*}{ weld } & 60.0 & \multirow{3}{*}{58.22} & Flawless \\
\hline 1.2 & & 57.33 & & Flawless \\
\hline 1.3 & & 57.33 & & Flawless \\
\hline 1.1 & \multirow{3}{*}{ HAZ } & 213.3 & \multirow{3}{*}{188.4} & Flawless \\
\hline 1.2 & & 213.3 & & Flawless \\
\hline 1.3 & & 138.6 & & Flawless \\
\hline 2.1 & \multirow{3}{*}{ weld } & 56.0 & \multirow{3}{*}{54.22} & Flawless \\
\hline 2.2 & & 53.33 & & Flawless \\
\hline 2.3 & & 53.33 & & Flawless \\
\hline 2.1 & \multirow{3}{*}{ HAZ } & 125.33 & \multirow{3}{*}{161.33} & Flawless \\
\hline 2.2 & & 214.66 & & Flawless \\
\hline 2.3 & & 144.00 & & Flawless \\
\hline 3.1 & \multirow{3}{*}{ weld } & 46.67 & \multirow{3}{*}{46.67} & Flawless \\
\hline 3.2 & & 46.67 & & Flawless \\
\hline 3.3 & & 46.67 & & Flawless \\
\hline 3.1 & \multirow{3}{*}{ HAZ } & 65.33 & \multirow{3}{*}{95.11} & Flawless \\
\hline 3.2 & & 112.0 & & Flawless \\
\hline 3.3 & & 108.0 & & Flawless \\
\hline
\end{tabular}

\section{Analysis of test results}

In order to check the effect of heat dissipation rate during welding on the properties of the austenitic steel joint, three test plates were made: an air-cooled plate, a water-cooled plate and a plate cooled with water spray from the ridge side. When joining the sheets, the TIG method was used to make the root run and welding with coated electrode in the case of filler runs.

Non-destructive and destructive tests were performed on the completed test plates. Visual, penetration and radiographic tests performed did not reveal any faults in welds, such as cracks, lack of fusion, blisters (Figs. 2, 3, 4). Additionally, the ferrite content $\delta$ was tested. The volume fraction of ferrite $\delta$ in the austenitic weld material depending on the operating conditions is strictly defined. The welding technique used and the selection of welding materials should guarantee the ferrite content in the austenitic weld within $2 \div 8 \%$ for manual welding and up to $10 \%$ for automatic welding. Appropriate ferrite content in the metal after welding prevents the possibility of hot cracking due to much better solubility of impurities in ferrite than in austenite. In the case of ASME regulations, sec. III [15] the minimum ferrite content in the weld measured by the FN ferrite number should not be less than $5 \mathrm{FN}$. In the tested test plates, the ferrite content $\delta$ decreases as the cooling speed of the test plate increases. However, in each case the ferrite content $\delta$ is in the range up to $8 \%$, while the ferrite number is in the range from 5.4 to $6.9 \mathrm{FN}$ (Table II). The ferrite content in the weld is related to impact strength. As the ferrite content $\delta$ decreases, the impact strength decreases, which may be related to the size of the crystallites and the kinetics of the transformation of ferrite into austenite during cooling, however, this requires further research (Table V, Fig. 5). The largest impact energy, both in the position of the notch in the weld and in the HAZ, occurs while cooling the test plate in air and amounts to $58.2 \mathrm{~J}$ and $188.4 \mathrm{~J}$, respectively (Table V). Welds are austenitic in structure with precipitation of $\delta$ ferrite with a vermicular structure (Fig. 5).

A static tensile test showed that the tensile strength of welded joints is slightly lower than the strength of the native material and is above $600 \mathrm{MPa}$ (Table III). The results of bending tests of all joints, both in the case of tensile stresses from the face and from the side of the ridge gave a positive result. The bending angle has reached $180^{\circ}$, which indicates good plastic properties. Visual tests of joints subjected to bending test did not show any presence of tears or cracks (Table IV). 

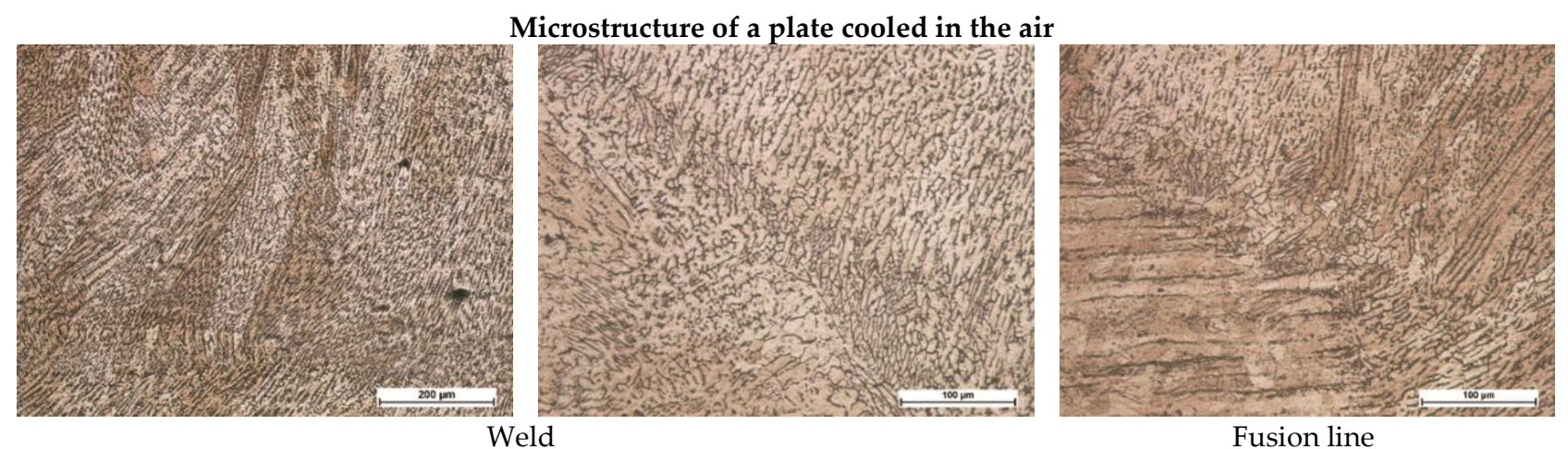

Microstructure of a plate cooled in the water

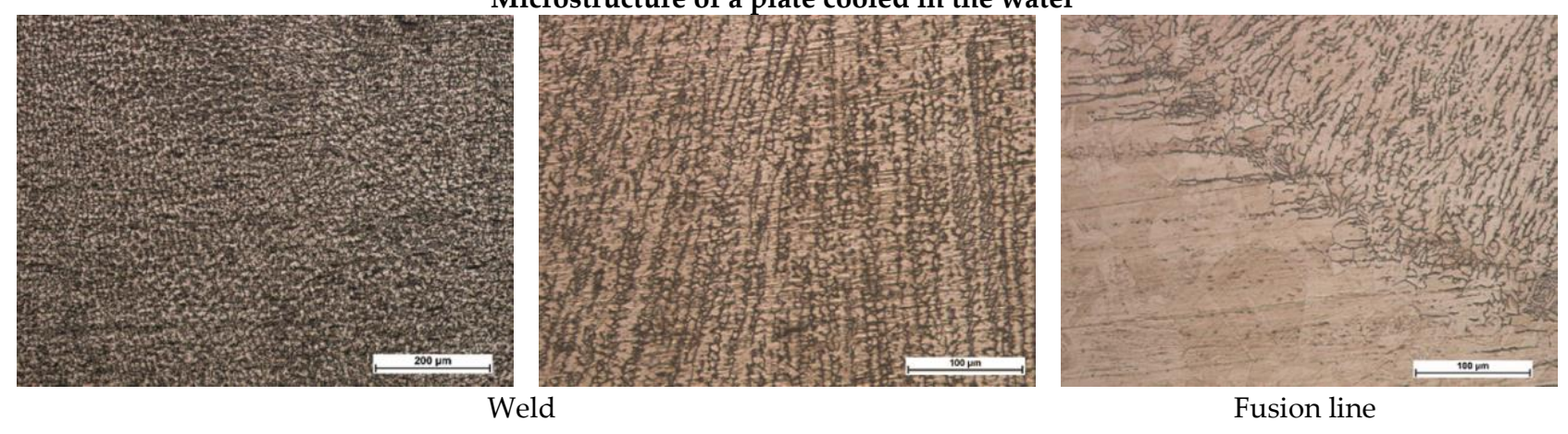

Microstructure of a plate cooled using water injection from the ridge side
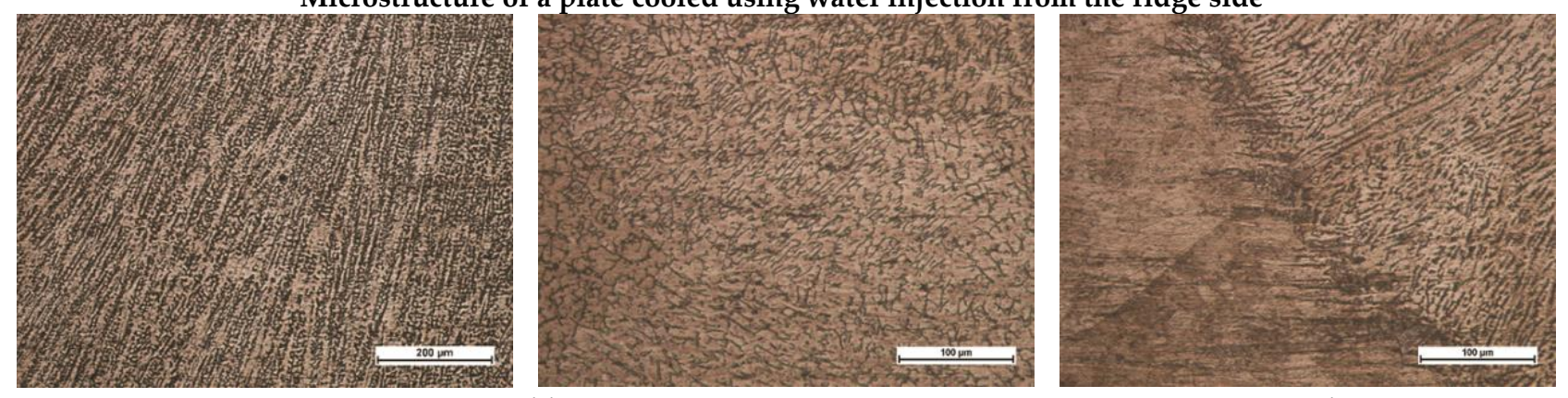

Weld

Fusion line

Fig. 5. Microstructure of the welded joint of test plates

\section{Conclusions}

1. The rate of heat dissipation did not affect the formation of surface and volume imperfections.

2. The static tensile test showed that the tensile strength of the welded joints of all test plates is slightly lower than the strength of the native material, however, it is higher than the required minimum value and is above $600 \mathrm{MPa}$.

3. A static bending test showed that all test plate joints have good plastic properties. The bending angle in each case reached $180^{\circ}$.

4. The ferrite content in the weld decreases as the cooling speed of the test plate increases and falls within the recommended range of $2 \div 8 \%$.

5. As the ferrite content decreases, the impact strength of the test plate joints decreases. The largest impact energy, both when the notch is in the weld and in the HAZ, occurs when the test plate is cooled in the air, while the smallest impact energy occurs when the test plate is cooled by spraying water from the ridge side.

Author Contributions: conceptualization M. M., P. D and A. R.; methodology M. M., A. R. and P. D.; validation A. R., P. D. and M. M.; formal analysis M. M, A. R.; investigation M. M, P. D.; resources A. R, M. M. and P. D.; data curation P. D, A. R., M. M..; writing-original draft preparation M. M. and A. R; writing -review and editing A. R.; visualization A. R.; supervision A. R, P. D..; project administration A. R.; funding acquisition A. R.

Conflicts of Interest: The authors declare no conflict of interest. 


\section{References}

[1] Pilarczyk J., i inni, Poradnik inżyniera, Spawalnictwo 1, Warszawa WNT 2005.

[2] Tasak E., Ziewiec A., Spawalność materiałów konstrukcyjnych Tom 1 Spawalność stali, wyd. JAK, Kraków 2009.

[3] McGuire M., Stainless steel for design engineers, ASM International, 2008.

[4] Lippold C.J., Kotecky D., Welding Metallurgy and Weldability of Stainless Steels, Wiley Interscience, 2005.

[5] Kotecki D., Armao F., Stainless steel properties, Lincoln Electric, 2003.

[6] Węgrzyn T., Hadryś D., Spawanie z chłodzeniem mikrojetowym propozycją nowej technologii napraw pojazdów, Zeszyty Naukowe Politechniki Ślaskiej, Transport, 2013, z. 78, 117-123.

[7] Samson K., Wpływ warunków spawania na właściwości złączy różnoimiennych stali odpornych na korozję, rozprawa doktorska, 2016.

[8] Stankiewicz M., Holloway G., Marhall A., Zhang Z., Ślązak B., Próba udarności Charpy'ego i parametr Lateral Expansion w ocenie materiałów spawalniczych dla potrzeb kriogeniki, Welding Technology Review, 2012 , Vol. 84(11), 2-11.

[9] Łabanowski J., Stale odporne na korozję i ich spawalność, Gdańsk, Wydawnictwo Politechniki Gdańskiej, 2018.

[10] Was G., Ukai S., Structural alloys for nuclear energy applications - austenitic stainless steel, 2019, $293-347$.

[11] Saluja R., Moeed, Assessment of Delta ferrite for SA 240 Type 304L Austenitic weld metal using different filler materials, International Journal of Scientific E Engineering Research, 2016, Vol. 7(2), 493-498.

[12] Bermejo M.A., Predictive and measurement methods for delta ferrite determination in stainless steels, Welding Journal, 2012, Vol. 91, 113-121.

[13] Saluja R., Moeed K., Formation, Quantification and Significance of Delta Ferrite for 300 Series Stainless Steel Weldments, International Journal of Engineering Technology, Management and Applied Sciences, 2015, Vol. 3, 23 -36.

[14] Sejc P., Kubicek R., Influence of heat input on the content of delta ferrite in the structure of 304 stainless steel GTA welded joints, Scientific Proceedings 2011, Vol. 19, 8-14. [CrossRef]

[15] ASME III Division 1, Rules for construction of nuclear power plant components, paragraph NB 2433.2.

(C) 2019 by the authors. Submitted for possible open access publication under the terms and conditions of the Creative Commons Attribution (CC BY) license (http://creativecommons.org/licenses/by/4.0/). 